\title{
Domestic technology, consumption economies of scale and poverty: Evidence from Sri Lanka
}

\section{DRAFT Please do not quote without permission of authors}

\author{
Author 1: Maneka Jayasinghe \\ Department of Accounting Finance and Economics, Griffith University, Nathan, Australia
}

Author 2: Shyama Ratnasiri

Department of Accounting Finance and Economics, Griffith University, Gold Coast, Australia

Author 3: Christine Smith

Department of Accounting Finance and Economics, Griffith University, Nathan, Australia

\author{
Author 4: Andreas Chai \\ Department of Accounting Finance and Economics, Griffith University, Gold Coast, Australia
}

Corresponding author: Maneka Jayasinghe

Corresponding Author's Email: maneka.jayasinghe@griffithuni.edu.au

\begin{abstract}
Acknowledgements
Maneka Jayasinghe wishes to acknowledge the financial support received from Griffith University to undertake Ph.D study programme. The authors wish to thank the Department of Census and Statistics, Sri Lanka, for providing access to Household Income and Expenditure Survey Data. They also gratefully acknowledge the comments and feedback on an earlier version of the paper received at the $12^{\text {th }}$ Australian Development Economics Workshop (ADEW), 2016 and the constructive comments offered by the anonymous reviewers.
\end{abstract}




\title{
Domestic technology, consumption economies of scale and poverty: evidence from Sri Lanka
}

\begin{abstract}
While it is well known that new technologies enhance consumer welfare, the manner in which these technologies impact the ability of households to realize economies of scale in consumption is not well understood. We use Sri Lankan household data to examine how the adoption of new technologies by households positively impacts their ability to achieve household economies of scale. This suggests that new technologies not only deliver a greater variety of consumption goods to consumers, but they may also play an important role in enabling large households to escape poverty by lowering the per-capita costs of maintaining a given standard of living. Given the importance of consumption economies of scale in the measurement of poverty, this study provides some insights on the extent to which the number of poor households changes when food consumption scale economies due to technology adoption in the domestic sphere are incorporated.
\end{abstract}

Keywords: food consumption, economies of scale, domestic technology adoption, poverty, developing countries

Subject classification codes: D12 I32 D63

\section{Introduction}

It is widely agreed that domestic technology adoption has lowered the cost of everyday household tasks, particularly by reducing the amount of labour required in the accomplishment of these tasks (De Vries 2008, Hall and Khan 2003, Mokyr 2000, Vanek 1978). For example, cooking food and related tasks, such as gathering firewood, consumes a significant amount of time of females, particularly in the rural areas of developing countries. Use of domestic technologies such as microwave ovens and refrigerators used in food preparation, processing, and preservation, and washing machines and clothes dryers used in the laundry saves time that can be spent on other tasks such as an income earning activity or even on leisure (Wickramasinghe 2011, Hossain 2010). Over time, there has been extraordinary growth in the use of technological equipment in the home environment, 
facilitated by increasing availability of low cost appliances and increasing household income levels (Bittman, Rice, and Wajcman 2004, Vanek 1978). Growing access to electricity, particularly in developing nations, has also enabled households in these nations to use electrical appliances at home, especially households in rural areas.

Beyond directly improving the welfare of consumer, this study empirically considers the possibility that these new technologies have impacted the distribution of poverty across large and small households. In particular, we argue that new goods have enabled large household to achieve significantly greater economies of scale in consumption, relative to small households. As a consequence, the adoption of new technologies, such as access to electricity, enables households to realize economies of scale in consumption and improve their living standards. To date, it is widely accepted that large households realize scale economies in consumption and face lower per-capita costs of maintaining a given material standard of living relative to small households (Nelson 1988). Understanding the magnitude and nature of these scale economies are vital for accurately measuring poverty levels (Kakwani and Son 2005, Logan 2011). In particular, estimates of these economies of scale are used to construct equivalence scales that enable researchers to compare welfare levels between households that vary in their size and compositions (Coulter, Cowell, and Jenkins 1992). However, the economic, social and behavioural factors that impact household economies of scale (and equivalence scales) are less well understood (Gibson 2002). Currently the three main sources considered in the current literature include the consumption of public goods, increasing returns in home production and bulk purchases (e.g. (Lanjouw and Ravallion 1995, Nelson 1988, Gan and Vernon 2003)). This literature provides basic intuition on a number of possible ways in which technological adoption in the domestic sphere may enhance greater household economies of scale in relation to aforementioned three 
sources. Some studies show that food preparation, preservation, and processing time and costs have seen a considerable reduction over the past several decades, particularly due to advancements in domestic technology and access to efficient energy sources (Popkin 1999). For example, access to refrigerators and deep freezers has allowed households to harvest economies of scale in meal production at home (Bittman, Rice, and Wajcman 2004). There have been several studies in the literature providing some evidence that bulk purchases of food have been on the rise in recent years due to increased use of facilities (such as refrigerators and freezers) to store perishable food items and increased access to transport (own automobiles and public transport services) (Tuttle 2011, Pena and Ruiz-Castillo 1998, Reardon et al. 2003). Cooking meals at home has become efficient with the use of electric stoves, microwave ovens and utensils such as grinders, blenders, etc. The use of microwaves, for example, has enabled households to reduce food waste by allowing them to store excess cooked food for later use. These developments may have facilitated more efficient use of scarce time within households and the ability to perform meal preparation related tasks with less toil. As a result, these households may be able to reap economies of scale in food consumption through increasing returns to scale in home production (Vernon 2005).

Given the historically rapid growth rate in the emergence of new goods and services in the $20^{\text {th }}$ century and their diffusion throughout the developing world (Popkin 1999, Bils and Klenow 2001), it is worth considering how these have affected the ability of large households to face lower per-capita costs in maintaining a given living standard. To date, much of the literature considering the welfare impact of new goods have mainly focused on how new technologies have delivered higher welfare by expanding the choice set faced by households (Hausman and Leibtag 2007). Less has been done to study the impact of new technologies on household economies of scale. 
This inattention in the existing literature is unfortunate due to three reasons. The incorporation of economies of scale arising from consumption of household goods appears to have a significant impact on the measurement of household poverty and welfare (Meenakshi and Ray 2002, Lanjouw and Ravallion 1995, Drèze and Srinivasan 1997, Coulter, Cowell, and Jenkins 1992, Buhmann et al. 1988). Conventional poverty measurements have often been criticised for overestimating poverty levels due to ignoring the possibilities of consumption economies of scale. Therefore, the negligence in identifying the impact of technology adoption in domestic sphere on consumption economies of scale may lead to a further overestimation of poverty levels. Secondly, an increasing number of households around the world, particularly in developing countries, are now using more technological equipment to ease the burden of domestic tasks. Therefore, it is important to analyse that how this increasing trend in domestic technology adoption has positively impacted on reducing their poverty levels. Thirdly, if there is adequate evidence to show that the consumption economies of scale deriving from technology adoption aids in curbing poverty levels, the adoption of appropriate technology at the domestic sphere can be promoted as a poverty reduction strategy. Therefore, it is important to carefully analyse the impact of domestic technology adoption on both consumption economies of scale and household poverty.

The most common way to control for the influence of consumption scale economies is by using equivalence scales. The Engel (1857) approach to constructing equivalence scales, which defines the household welfare as the percentage of total household expenditure spent on food consumption has been widely used in the literature to estimate equivalence scales which account for consumption economies of scale. In this study, we use the same approach to measure the economies of scale in food consumption due to domestic technology adoption. 
Based on the definitions associated with the Engel method, we treat the expenditure share devoted to food is an indicator of a household's standard of living and welfare.

The objective of this study is twofold: (1) to theoretically and empirically investigate the effects of technology adoption in the domestic sphere on food consumption scale economies using Engel equivalence scales; and (2) to re-estimate the poverty rates for Sri Lanka to quantify this consumption economies of scale effect on existing poverty levels in the country. ${ }^{1}$ To this end, we test the hypothesis that the use of appropriate technology in the domestic sphere is associated with greater economies of scale in food consumption. As the degree of technology adoption is difficult to measure, household expenditure on electricity is used as a proxy variable for technology adoption. If confirmed, we argue that those households who have access to electricity have lower per-capita expenditure (PCE) on food than their counterparts who do not use domestic technology. If poverty rates are re-estimated, allowing for these economies of scale in food consumption due to technology adoption, those households who do not have access to appropriate domestic technology, often poor households, may be even poorer in a relative sense than suggested by per-capita based poverty measures. Therefore, our analysis of the effects of technology adoption on household economies of scale is expected to provide some important insights on the current poverty status in Sri Lanka, and other developing countries with similar socio-economic backgrounds.

\footnotetext{
${ }^{1}$ The motivation for such an analysis stems from the results of our analysis of intertemporal changes in food consumption economies of scale. In an investigation on how the food consumption economies of scale changes over the period of 1990 to 2009, in Sri Lanka, we found that such economies of scale demonstrate an increasing trend. When exploring the factors that may contribute to such increases in food economies of scale, we identified access to domestic technology may explain our observations. As a consequence, in this current paper, we have attempted to verify our hypothesis that household access to domestic technology enables them to achieve greater economies of scale both theoretically and empirically. The findings of this earlier intertemporal paper were presented at the $6^{\text {th }}$ Meeting of the Society for the Study of Economic Inequality, Luxembourg 2015.
} 
The paper is structured as follows. Section II presents a utility maximizing model of households that highlights how the adoption of domestic technology enhances consumption economies of scale. Section III discusses the data employed in this study, while section IV outlines the empirical methodology adopted. Section V presents the results and discusses their implications for poverty status. Section VI concludes.

\section{Theoretical model}

A household comprises $n$ identical individuals who derive utility by consuming two goods $x_{i}$, where $i=1,2$. Let $i=1$ denote food and $i=2$ denote non-food items. The household preferences are given by a Cobb-Douglas utility function as:

$u\left(x_{1}, x_{2}\right)=x_{1}^{a} x_{2}^{b}$

where $x_{1}$ and $x_{2}$ are the quantities consumed of food and non-food items, respectively. The notation $a$ denotes the demand elasticity of food and $b$ denotes the demand elasticity of nonfood items. Households maximise utility subject to a budget constraint, which is given by:

$p_{1} x_{1}+p_{2} x_{2} \leq I$

where $p_{1}$ is price of food, $p_{2}$ is price of non-food items, and $I$ is household income.

The rest of the model is constructed on food $x_{1}$, as we are interested in exploring the economies of scale in food consumption. Household food consumption is determined by the price, income, and the preferences of the household unit. The optimal consumption of food $x_{1}$, based on the standard optimisation solution, yields: 
$x_{1}=\frac{a}{a+b} \frac{I}{p_{1}}$

The optimal consumption of $x_{1}$ can also be referred to as the "unadjusted" household food consumption, as it is not adjusted for possible food consumption economies of scale. However, in the presence of economies of scale, the "actual" or "adjusted" household consumption is different from the optimal consumption level denoted by Equation (3). What follows illustrates how the optimal consumption can be adjusted to incorporate economies of scale of food consumption.

Consumption economies of scale may occur as a result of two factors. They comprise:

i) Household size $(n)$ : This refers to the ability of large households to enjoy economies of scale from bulk purchases, quantity discounts, and substitution of home-produced meals for expensive food-away-from-home (Nelson 1988), and

ii) Degree of technology adoption in the domestic sphere $(\tau)$ : This refers to the ability of households to achieve economies of scale by adopting technology to assist food consumption. For example, having access to electricity allows them to purchase perishable food items in bulk and store them for a long time. Furthermore, the increasing returns to scale in home production of food, which is also a source of economies of scale, may depend on the access to domestic technology such as household utensils and appliances that save time and effort of the people who engaged in food preparation activities. For example, if there are electric stoves at home, not only they save time spent on cooking using traditional fire, but also not having to collect firewood for cooking purposes saves time for people in the family. The time efficiency in food production at home, then, may encourage 
households to eat more home-prepared meals. We composite all these effects into technology adoption in our model and measure this by the degree of technology adoption.

Next, we introduce the possibilities of food consumption economies of scale arising due to household size and technology into our model and present household optimal food consumption in terms of "actual" or "adjusted" household food consumption. Such economies of scale effects are represented by the $\phi_{1}$ parameter. and modelled as:

$$
\phi_{1}(n, \tau)=n^{1-\sigma_{1}}(1+\tau)^{1-\alpha_{1}}
$$

where $n$ is household size and $\left(n^{1-\sigma_{1}}\right)$ is the economies of scale effect of household size, $\tau$ is the degree of technology adoption, and $(\tau)^{1-\alpha_{1}}$ is the economies of scale effect of the technology adoption in the domestic sphere. Here $\sigma_{1}$ is the scale elasticity of food with respect to household size while $\alpha_{1}$ is the scale elasticity of food induced by the use of domestic technology to aid consumption of food. Both these scale elasticities are assumed to range between 0 and $1\left(0 \leq \sigma_{1} \leq 1\right.$ and $\left.0 \leq \alpha_{1} \leq 1\right)$. In the context of the modelling the degree of technology adoption, $\tau$ is a parameter that can vary from 0 and 1 , where 1 indicates a fully automated food preparation process.

Consequently, the economies of scale parameter $\left(\phi_{1}(n, \tau)\right)$ can range from $n(1+\tau)$ to 2 (i.e. $\left(n(1+\tau) \leq \phi_{1}(n, \tau) \leq 2\right)$ ), where $\phi_{1}(n, \tau)=n(1+\tau)$ implies no economies of scale and $\phi_{1}(n, \tau)=2$ implies full economies of scale arising from both household size and technology. For example, if the good is a pure public good that provides full economies of scale (i.e. $\sigma_{1}=1$ ), and the consumption of that good involves a fully automated processes

\footnotetext{
${ }^{2}$ This model is an extension of (Vernon 2005).
} 
with $\tau=1$, then the scale parameter is $\phi_{1}(n, \tau)=2$. A desktop computer, which can be shared among the household members and that requires technology to assist deriving utility represents a conceivably good example for this type of public good.

On the other hand, if the good is a pure private good there are no economies of scale generating from household size $(n)$ (i.e. $\sigma_{1}=0$ ) and no economies of scale effect is derived from technology (i.e. $\alpha_{1}=0$ ), as the degree of technological adoption is 0 (i.e. $\tau=0$ ) and so Equation (4) simplifies in to $\phi_{1}(n, \tau)=n$. This implies that the good is a private good that cannot be shared, and hence the good must be fully replicated if all the members in the household are to enjoy the good to the same degree as a single person household and no technology is involved in consumption of this good. There is another extreme situation possible where $\sigma_{1}=0$, yet $\tau>0$, and hence the scale parameter $\left(\phi_{1}(n, \tau)\right)$ can be affected. If the good is pure private good and no economies of scale effect derives from household size (n) (i.e. $\sigma_{1}=0$ ) and no economies of scale effect emerges from technology (i.e. $\alpha_{1}=0$ ), although the household has full access to technology (i.e., $\tau=1$ ), Equation (4) simplifies to $\phi_{1}(n, \tau)=n(1+\tau)$. This is because although a household has access to technology, the consumption of some goods does not require any technological input. A sightseeing ticket or a ticket for a sports event that cannot be shared, and does not require any technological input for deriving utility, represents an example for this type of pure private good.

Based on the above discussion, the adjusted/actual household consumption of food $x_{1}^{*}$ is given as:

$$
x_{1}^{*}=\frac{x_{1}}{\phi_{1}(n, \tau)}
$$


Substituting Equations (3) and (4) in to the above (Equation (5)) and rearranging we obtain:

$$
x_{1}^{*}=\frac{a}{a+b} * \frac{I}{p_{1}} * \frac{1}{n^{\left(1-\sigma_{1}\right)_{*}(1+\tau)^{\left(1-\alpha_{1}\right)}}}
$$

The notation $x_{1}^{*}$ denotes the adjusted household demand for food. Equation (6) can be presented in per-capita terms to show the adjusted per-capita demand for food as:

$$
\frac{p_{1} x_{1}^{*}}{n}=\left(\frac{a I}{a+b} * \frac{1}{n^{\left(1-\sigma_{1}\right) *(1+\tau)^{\left(1-\alpha_{1}\right)}}}\right) \frac{1}{n}
$$

When taking the log of both sides, the log of adjusted per-capita food consumption is:

$$
\ln \left(\frac{p_{1} x_{1}^{*}}{n}\right)=a \ln (I)-\ln (a+b)-\left[\left(2-\sigma_{1}\right) \ln n\right]-\left[\left(1-\alpha_{1}\right) \ln (1+\tau)\right]
$$

The third term of this Equation (8) suggests that per-capita food expenditure holds a negative relationship with (log of) household size. Because there are economies of scale in food consumption, the per-capita spending on food will decline as household size grows. The negative coefficient in the fourth term suggests that the per-capita food expenditure is inversely related to the (log of) degree of technology adoption in the domestic sphere. This is because household food consumption and food production assisted by domestic technology enables households to enjoy more consumption scale economies. As a result, per-capita food consumption declines with higher technology adoption.

To verify this theoretical proposition, we empirically estimate Equation (8). We take ( $\log$ of) PCE on food as the dependent variable with (log of) household size $n$ and (log of) 
technology share $\tau$ as independent variables. If the estimated coefficients of these two parameters are found to have a negative relationship with per-capita food expenditure, this would indicate that household size, as well as adoption of domestic technology to assist food consumption enhances food consumption economies of scale. In case of the absence of domestic technology, households would still enjoy economies of scale arising due to household size. However, those households who adopt more domestic technology in relation to food consumption can achieve higher economies of scale, and thereby lower their percapita food consumption expenditure more than those who do not use domestic technology in this way. In this study, we consider access to electricity as a reasonable proxy to indicate domestic technology adoption, while the expenditure share on electricity is used as proxy variable for degree of technology adoption $(\tau)$.

\section{Data}

\section{Profile of the sample}

The analysis in this study is based on the 2009/10 Household Income and Expenditure Survey (HIES) conducted by the Department of Census and Statistics (DCS) in Sri Lanka. The 2009/10 HIES full sample comprises 19,958 households and excludes three districts in the Northern province of the country (Mannar, Killinochchi and Vavuniya) due to resettlement activities which took place after the civil war at the time of this census being conducted. After dropping outliers and missing values, the sample size reduced to 18,819 , which we have used for further analysis. Table 1 provides some basic descriptive statistics about the sample.

The sample consists of 4,963 urban, 12,192 rural and 1,664 estate sector households. The urban sector refers to all areas administered by municipal and urban councils. The estate sector comprises all plantations, which are 20 acres or more in extent and employ ten or more 
resident labourers. All areas other than urban and estate are classified as the rural sector. The response rate was approximately 80 per cent in each sector (Department of Census and Statistics 2011a). According to Table 1, at the national level, about 16,158 households (86 per cent) in the sample have access to electricity. In the urban sector, about 4,713 households (95 per cent) have access to electricity, while in the rural and estate sector it is about 84 and 71 per cent, respectively.

\section{[Table 1 about here]}

The survey provides data on food and beverages and non-food expenditures of households. Expenditure on food and beverages (hereafter referred to as expenditure on food) covers 18 sub-categories. ${ }^{3}$ Expenditure on non-food items covers 10 additional subcategories. ${ }^{4}$ Expenditure on some non-food items are measured on an annual or bi-annual basis to smooth seasonal effects on spending. Hence, in this analysis, all of the expenditure figures are converted to monthly data to match other expenditure categories as necessary. Table 2 provides household expenditure share on food and beverages, alcohol, and non-food items. During the survey period, the lowest foodshare is recorded in the urban sector (41 per cent) followed by the rural sector (45 per cent) and estate sector (51 per cent). On average, households spend about 2 per cent of their total expenditure on electricity, at the national level, and in the urban and rural sector. In the estate sector, about 1 per cent of household expenditure is spent on electricity.

\footnotetext{
${ }^{3}$ These categories comprise cereal, prepared food, pulses, vegetables, yams, meat, fish, dried fish, eggs, coconuts, condiments, other foods, milk \& milk products, fats \& oils, sugar, fruits, confectionery and non-alcoholic beverages (Department of Census and Statistics 2011a).

${ }^{4}$ These categories comprise housing \& household services, fuel \& lighting, personal care, health care, transport, communication, recreation, education, clothing \& footwear and other ad hoc expenditure. Certain non-food expenditure items include some imputed expenditure elements (e.g. the rental value of owner-occupied housing and the value of free housing, particularly in the estate sector) (Department of Census and Statistics 2011a).
} 
[Table 2 about here]

\section{Access to electricity}

Sri Lanka's electricity generation has been gradually moving from a predominantly hydroelectric system to a mixed hydro-thermal system. Households use about 40 per cent of total electrical energy produced in the country. There has been a remarkable increase in access to electricity over the last two decades. For example, the percentage of electrified households has grown from 29 per cent in 1990 to 63 per cent in 2001 and 85 per cent in 2010. By 2012, access to electricity has increased further to 94 per cent (Ceylon Electricity Board 2012). By 2010, about 96 per cent of urban households in the country were electrified. With the introduction of reforms to the national energy policy in 2002, much of the attention was given to enhancement of rural electrification. As a result, the percentage of electrified households in the rural sector has seen an unprecedented increase from 47 per cent in 2001 to 84 per cent in 2010 (Ceylon Electricity Board 2008, 2011)

Nevertheless, substantial disparities in access to electricity still exist across the provinces. For example, while electrification in Western and Southern provinces exceeds about 97 per cent, in the lagging Uva province only about 30 per cent of households had access to electricity by 2012 (Ceylon Electricity Board 2012). The main reason for the latter is lack of access to the grid. In particular, the remaining households are situated a significant distance away from the grid, making connection cost higher. The low-income households in these areas are unable to afford this connection cost, as it is not subsidised (Siyambalapitiya 2002). Furthermore, significant disparities in electrification rates can also be seen in Northern and Eastern provinces where the civil conflict was taking place till 2009. This is because the 
severely war damaged distribution network has prevented the development of new rural electrification programmes in these provinces (Ceylon Electricity Board 2012).

Figure 1 illustrates the change in household electrification, by sector, during the last two decades. The highest growth, of about 34 per cent, in the percentage of electrified households is seen during the period of 1990 to 2001. During the period of 2001 to 2010, the growth is about 22 per cent. By 2001, about 85 per cent of urban household had access to electricity, however only about 47 and 38 per cent of rural and estate sector households were electrified. During the period of 2001 to 2010, the percentage of electrified households in the estate and rural sector has increased by about 40 and 37 per cent, respectively. The growth in the urban sector, however, is just over 10 per cent. Compared to the urban sector, the proportion of households with access to electricity is still lower in the rural and estate sector.

\section{[Figure 1 about here]}

This study represents the first attempt at analysing these matters using data from a developing country like Sri Lanka. The richness of the HIES dataset, with detailed information on household expenditure, provides a splendid opportunity to examine the effects of domestic technology adoption on household food consumption economies of scale. The next section presents the empirical methodology adopted in this study.

\section{Empirical methodology}

\section{Per-capita expenditure on food}

In this section, we empirically estimate the theoretical model we derived in Section II. To this end, the $\log$ of per-capita food expenditure $\ln \left(F_{p c}\right)$ is regressed with a set of 
independent variables, including $\log$ of household size $\ln (n)$ and $\log$ of household expenditure share on electricity $\ln \left(E E_{\text {share }}\right)$. As discussed in Section III, we expect both $\ln (n)$ and $\ln \left(E E_{\text {share }}\right)$ to demonstrate a negative relationship with $\ln \left(F_{p c}\right) .{ }^{5}$ This is because, due to economies of scale arising from household size and adoption of technology in the domestic sphere, the larger the family size and higher the degree of technology adoption measured in terms of expenditure share on technology, the lower is the expected PCE on food. The variable $\ln (n)$ is also expected to possess a negative relationship with $\ln \left(F_{p c}\right)$ due to household size induced CSE in food consumption. The other independent variables used in the model include $\log$ of PCE, $\ln \left(E_{p c}\right)$, and a vector of demographic variables $\boldsymbol{K}$ which consist of the gender of the head of the household, as well as two location dummy variables for the rural and estate sectors. $\varepsilon$ is the random error term. The resulting regression specification is as follows:

$\ln \left(F_{p c}\right)=\beta_{0}+\beta_{1} \ln (n)+\beta_{2} \ln \left(E E_{\text {share }}\right)+\beta_{3} \ln \left(E_{p c}\right)+\boldsymbol{\delta}^{\prime} \boldsymbol{K}+\varepsilon$

In estimating Equation (9) by OLS, we need to be mindful that there is a possibility for endogeneity in the model. It was recognized that as the food expenditure $F_{p c}$ is expected to be correlated with the error term $\varepsilon$ of Equation (9) while the food expenditure $F_{p c}$ is also a component of total consumption expenditure $E_{p c}$ (which include both food and non-food expenditure). To address possible endogeneity concerns arising from the inclusion of PCE, we use an Instrumental Variable (IV) approach. The IV estimator provides a consistent estimator if: (1) the IV variable does not have a direct effect on the dependent variable; (2) it is not correlated with the regression error term; and (3) it is strongly correlated with the

\footnotetext{
${ }^{5}$ Note that we added a constant " 1 " to the electricity expenditure share before log transforming, i.e. we used $\ln \left(1+E E_{\text {share }}\right)$. This is to circumvent the problem of zero values being log transformed as missing or undefined values (Hamilton 2008).
} 
exogenous explanatory variable, in this case the total consumption expenditure $E_{p c}$ (Hill, Griffiths, and Lim 2011). Accordingly, we have selected the number of employed members in the household as an IV for PCE. This IV is expected to have a strong correlation with PCE, but not to have a direct effect on the per-capita food expenditure and hence this IV appears to satisfy the properties of a suitable IV. In Section V we present the results of our empirical estimations of Equation (9) using the IV estimation method and the results of post-estimation tests to validate the decision to select IV regression over OLS and the selected IV.

\section{Economies of scale in electricity use}

As mentioned above, household access to electricity is an important consideration of this study, as it is used as a proxy variable for household access to technology. The main objective of this study is to examine the effects of technology adoption in realizing food consumption scale economies. Nevertheless, it is also important to highlight here that we anticipate economies of scale in consumption of technology (as proxied by the consumption of electricity) in large households. As such, the PCE on technology is expected to decline with household size. To test this notion of economies of scale in technology use, we estimate a Heckman two-step model (Heckman 1976), also known as a type-2 Tobit. The choice of a Heckman model was necessary due to the zero electricity expenditure observed in some households. In the sample used in this study, reported electricity expenditure values are zero for 14.13 per cent of the total households. The Heckman model is widely used in the analysis of household expenditure where the spending is considered to be based on two steps - the decision to spend and the amount spent (Cameron and Trivedi 2010). In the context of analysing the household electricity spending behaviour, a probit model (hereinafter referred to as the selection equation) is first estimated explaining the household decision to spend on electricity or not. The Probit estimates are then used to determine the Inverse Mills ratio 
(IMR) for the $h^{\text {th }}$ household and the $i^{\text {th }}$ commodity. In the second step, an OLS regression (hereinafter referred to as the outcome equation) is estimated relating to the amount spend on electricity, in which the IMR features as an additional explanatory variable. This IMR accounts for the fact that the observed sample of households who choose to spend on electricity is not random. In the actual estimation, the two-steps were estimated jointly by maximum likelihood, using the STATA package.

Based on the existing literature on the determinants of household demand for electricity (Louw et al. 2008, Ekholm et al. 2010, Ouedraogo 2006, Davis 1998) and based on the availability of data, the selection and outcome equations were specified as follows.

\section{Selection equation}

We selected a set of independent variables that determine the household decision to spend on electricity, namely household size $n$; the square of household size $\left(n^{2}\right)$; the log of per-capita income $(\mathrm{PCI}), \ln \left(I_{p c}\right)$, and a vector of demographic indicators $\boldsymbol{K}$ (i.e. age of the head of the household, two location dummy variables, one for rural and another for estate sector, and a third dummy variable for the gender of the household head). The corresponding coefficient vector is denoted by $\boldsymbol{\delta}=(\delta 1, \delta 2, \delta 3, \delta 4)$. The error term is $\varepsilon$. The dependent variable is the probability of spending on technology (proxied by expenditure on electricity ELEC). The resulting Probit specification of the electricity demand equation is given by:

$$
\operatorname{Pr}[E L E C>0]=\beta_{0}+\beta_{1} n+\beta_{2}\left(n^{2}\right)+\beta_{3} \ln \left(I_{p c}\right)+\boldsymbol{\delta}^{\prime} \boldsymbol{K}+\varepsilon
$$

\section{Outcome equation}

The outcome equation includes the same set of independent variables specified in the selection equation, excluding gender and age of the head of the household. For a more robust identification of the model, such exclusion is necessary (Cameron and Trivedi 2010). The 
exclusion was determined based on the idea that while the age and the gender of the head of the household affects the household decision to spend on electricity or not, it does not affect how much is spent. The resulting Probit specification of the electricity demand equation is

$E L E C=\beta_{0}+\beta_{1} n+\beta_{2}\left(n^{2}\right)+\beta_{3} \ln \left(I_{p c}\right)+\boldsymbol{\delta}^{\prime} \boldsymbol{K}+\varepsilon$

where ELEC is the expenditure on electricity and $\mathrm{K}$ includes two location dummy variables for the rural and estate sectors.

Electricity expenditure is expected to be positively correlated with household size $n$, accompanied by a negative square of household size coefficient $(n)^{2}$. This is because, as suggested in the literature, expenditure on electricity is expected to increase at a decreasing rate due to $\mathrm{CSE}$ in electricity consumption. Household income $\beta_{3}$ is expected to hold a positive relationship with electricity expenditure (Louw et al. 2008, Ekholm et al. 2010, Ouedraogo 2006, Davis 1998, Chambwera and Folmer 2007). In comparison to the urban sector, the rural and estate sectors are expected to demonstrate a negative relationship with electricity expenditure, due to socio-economic differences as well as the differences in access to electricity in the three sectors discussed in Section III. Furthermore, the magnitude of the negative relationship is expected to be higher in the estate sector (listed under $\delta$ ), as the estate sector households, compared to their rural counterparts (listed under $\delta$ ), are particularly vulnerable in many aspects of social and economic well-being.

\section{Impact on household poverty}

We also quantify the effects of food consumption economies of scale arising from the adoption of domestic technology to aid food consumption on household poverty. The intention here is to identify how many households who are currently living below the official 
poverty line may, by contrast, actually place above the poverty line when food consumption economies of scale generated from the use of domestic technology are taken into account. We do this by adjusting household expenditure on food, in households those who have access to electricity, for possible economies of scale in food consumption arising due to technology adoption. To this end, we first estimate the percentage of poor households, using PCE. The percentage of poor households is the percentage of households whose PCE fall below the official poverty line (Department of Census and Statistics 2011a). The official poverty line used here is Rs.3028 real total expenditure per person (Department of Census and Statistics 2011b).

To adjust the PCE of these households for food economies of scale arising from technology adoption, we calculate expenditure per-equivalent adult. For this purpose, we use our empirical results on linear Engel equivalence scales for food, for households who have access to technology (proxied by access to electricity) ${ }^{6}$. The expenditure per-equivalent adult is estimated by dividing the household expenditure by equivalence scales of respective households, instead of household size. The equivalence scale of a particular household size is less than the actual household size (with the exception of single-adult households), due to possible economies of scale. As such, the resulting expenditure per-equivalent adult is slightly higher than the PCE of a particular household. ${ }^{7}$ We then estimate the number of poor households that we initially identified under the per-capita method who move above the

\footnotetext{
${ }^{6}$ Equivalence scales measure the changes in income required to bring households of different sizes and compositions to the same welfare level (Nelson 1993). The use of equivalent incomes also allows adjustments to be made for such consumption scale economies (Deaton and Muellbauer 1980). A detailed discussion on the estimation procedure of equivalence scales under Engel method can be found in Jayasinghe et al. (2016).

${ }^{7}$ Note that, for the sake of simplicity, we assumed that economies of scale were absent in other expenditure categories, and hence use PCE for expenditure categories other than the expenditure on food.
} 
poverty line when the expenditure per equivalent adult, which allow for possibilities of economies of scale in food consumption due to technology adoption, is used.

\section{Empirical results}

\section{Results on per-capita expenditure on food}

The IV regression estimates of PCE on food are given in Table 3. Model I results are from the first stage regression, while Model II results are from the IV regression estimation. Considering the IV regression estimates corresponding to Equation (9), as expected in the theoretical model, the household size elasticity of per-capita food expenditure $\left(\beta_{1}\right)$ is -0.124 , which is negative, implying that when household size increases by 10 per cent, we expect the PCE on food to decline by about 1.24 per cent. This reflects the economies of scale in food consumption, with respect to household size. Furthermore, as suggested in our theoretical model, the (log of) electricity expenditure share $\left(\beta_{2}\right)$ also takes a negative value -0.692 , suggesting that a 10 per cent increase in expenditure share on electricity is associated with about 6.92 per cent reduction in PCE on food. As our theoretical model suggested, this reduction in per-capita food expenditure is due to economies of scale arising from technological adoption in the domestic sphere.

The Durbin-Wu-Hausman $(\mathrm{DWH})$ test results of $\mathrm{F}(1,18811)=10.5595$ with $\mathrm{p}$-value $=$ 0.0012 (see Table 4) lead to a strong rejection of the null hypothesis that PCE is exogenous. Therefore, we conclude that PCE is endogenous. The diagnostic test results for weak instruments are given in Table 5. The $\mathrm{R}^{2}$ and Adjusted $\mathrm{R}^{2}$ values of 0.1934 and 0.1932 , respectively, reveal that they are not low enough to flag a weak identification. As suggested by Cameron and Trivedi (2010), the $F$ statistic of 92.29 (with a p-value 0.00 ) is considerably 
larger than the rule of thumb value of 10 and hence the number of employed members does not seem to be a weak instrument.

[Table 3 about here]

[Table 4 about here]

[Table 5 about here]

\section{Results on economies of scale in consumption of technology}

The results of the Heckman two step model are given in Table 6. All of the coefficients are significant at the 5 per cent level. In the output equation, as anticipated, the household size $\left(\beta_{1}\right)$ variable possesses a positive relationship with household demand for electricity. This is accompanied by a negative coefficient for the square of household size variable $\left(\beta_{2}\right)$. This inverted U-shape relationship implies that the household demand for electricity increases at a decreasing rate with household size. This is due to economies of scale in consumption in electricity in large households (Chambwera and Folmer 2007). As evident in Ekholm et al. (2010) the coefficient of the log of PCE variable $\left(\beta_{3}\right)$ shows that the demand for electricity increases with income. In comparison to urban households, the demand for electricity is lower among the rural households and it is even lower among the estate sector households. This observation further confirms that household location is an important factor that determines household expenditure on electricity (Ekholm et al. 2010, Kanagawa and Nakata 2008).

[Table 6 about here]

\section{Impact on household poverty}


We also quantify the effects of food consumption economies of scale arising from the adoption of domestic technology on household poverty. We do this by adjusting household expenditure on food, in households those who have access to electricity, for possible economies of scale in food consumption arising due to technology adoption. The results, using the method described in the methodology section above, are given in Table 7.

Insert Table 7 here

\section{Policy implications and concluding remarks}

This study examined the effects of domestic technology adoption on food consumption scale economies, using data from Sri Lanka for the period of 2009/10. A theoretical model was developed to identify how the domestic technology adoption may enable households to achieve higher FCSE. The validity of this model was tested using regression analysis. In the actual estimation, the expenditure on electricity was used as a proxy variable to denote expenditure share on domestic technology. Empirical results revealed that higher expenditure shares on technology are associated with lower PCE on food. This is because the adoption of domestic technology, together with electrification, appears to reduce their food preparation, processing, and preservation cost. Furthermore, the reduction in time required to perform food preparation related activities, with the use of domestic technology, may have encouraged time scarce households to prepare food at home rather than having meals prepared outside. This may have enabled these households to reap the benefits of consumption economies of scale through increasing returns to scale in home production. Our 
results also indicate that a significant number of households who have been categorised as poor, based on per-capita measures, appear to move out of poverty, if food consumption economies of scale realised through domestic technology adoption is allowed for. The novelty of this study was to link technology adoption to the analysis of economies of scale from the consumption aspect, and thereby to incorporate the economies of scale effect of domestic technology adoption in the measurement of poverty.

The role of improved access to efficient energy sources and technology adoption has received significant attention in augmenting the welfare of the population. Facilitating access to efficient energy sources has been widely applied as a part of the development agenda in many developing countries. The findings of this study further reinforce the importance of household electrification and the adoption of an appropriate level of technology in everyday life. In terms of policy implications, these results highlight the necessity for policies that encourage enhanced levels of household electrification and domestic technology adoption. Provision of subsidies that allow for a greater level of access to electricity in rural areas, and subsidising the electricity prices for low-income households in disadvantaged areas within the rural and estate sectors, for example, could act to improve the standard of living of these households in a well-targeted manner (Global Energy Assessment 2012). Policies directed towards increased use of solar-power to generate electricity such as sharing relevant information on the benefits of solar-power, introducing rebates for households to installing solar panels, and subsidising the installation of solar panels for very poor households, may be considered. This may be especially useful in those rural areas where access to the grid is prohibitively expensive. Furthermore, allocation of funding, or provision of interest-free loans for low-income households to purchase energy saving domestic appliances, may also be a valuable option to consider. This may not only make their transition from traditional methods to technologically advanced and efficient methods (that enable greater food 
consumption scale economies) both smoother and financially less stressful, but it may also ease the burden of their electricity bills in the longer term. 


\section{References}

Bils, Mark, and Peter J. Klenow. 2001. "The Acceleration in Variety Growth." The American Economic Review 91 (2):274-280. doi: 10.1257/aer.91.2.274.

Bittman, Michael, James Mahmud Rice, and Judy Wajcman. 2004. "Appliances and Their Impact: The Ownership of Domestic Technology and Time Spent on Household Work." The British Journal of Sociology 55 (3):401-423. doi: 10.1111/j.14684446.2004.00026.x.

Buhmann, Brigitte, Lee Rainwater, Guenther Schmaus, and Timothy M Smeeding. 1988. "Equivalence Scales, Well-Being, Inequality, and Poverty: Sensitivity Estimates across Ten Countries Using the Luxembourg Income Study (LIS) Database." Review of Income and Wealth 34 (2):115-142.

Cameron, Adrian Colin, and P. K. Trivedi. 2010. Microeconometrics using Stata. College Station, Tex: Stata Press.

Ceylon Electricity Board. 2008. Annual Report. Colombo: Ceylon Electricity Board.

Ceylon Electricity Board. 2011. Annual Report. Colombo: Ceylon Electricity Board.

Ceylon Electricity Board. 2012. Annual Report. Colombo: Ceylon Electricity Board.

Chambwera, Muyeye, and Henk Folmer. 2007. "Fuel Switching in Harare: An Almost Ideal Demand System Approach." Energy Policy 35 (4):2538-2548. doi: 10.1016/j.enpol.2006.09.010.

Coulter, Fiona A. E., Frank A. Cowell, and Stephen P. Jenkins. 1992. "Differences in Needs and Assessment of Income Distributions." Bulletin of Economic Research 44 (2):77124. doi: 10.1111/j.1467-8586.1992.tb00538.x.

Davis, Mark. 1998. "Rural Household Energy Consumption: The Effects of Access to Electricity- Evidence from South Africa." Energy Policy 26 (3):207-217.

De Vries, Jan Nov. 2008. The Industrious Revolution: Consumer Behavior and the Household Economy, 1650 to the Present. Cambridge;New York;: Cambridge University Press.

Deaton, Angus, and John Muellbauer. 1980. Economics and Consumer Behavior. Cambridge: Cambridge University Press.

Department of Census and Statistics. 2011a. Household Income and Expenditure Survey 2009/10. Colombo: Department of Census and Statistics.

Department of Census and Statistics. 2011b. Poverty Indicators. Colombo: Department of Census and Statistics.

Drèze, Jean, and P.V. Srinivasan. 1997. "Widowhood and Poverty in Rural India: Some Inferences from Household Survey Data." Journal of Development Economics 54 (2):217-234. doi: 10.1016/S0304-3878(97)00041-2.

Ekholm, Tommi, Volker Krey, Shonali Pachauri, and Keywan Riahi. 2010. "Determinants of Household Energy Consumption in India." Energy Policy 38 (10):5696-5707. doi: 10.1016/j.enpol.2010.05.017.

Engel, Ernest. 1857. "Die lebenskosten Belgischer arbeiter-familien fruher und jetzt." International Statistical Institute Bulletin 9:1-74.

Gan, Li, and Victoria Vernon. 2003. "Testing the Barten Model of Economies of Scale in Household Consumption: Toward Resolving a Paradox of Deaton and Paxson." The Journal of Political Economy 111 (6):1361-1377. doi: 10.1086/378534.

Gibson, John. 2002. "Why does the Engel Method Work?: Food Demand, Economies of Size and Household Survey Methods." Oxford Bulletin of Economics and Statistics 64 (4):341-359. doi: 10.1111/1468-0084.00023.

Global Energy Assessment. 2012. In Global Energy Assessment - Toward a Sustainable Future. Cambridge: International Institute for Applied Systems Analysis. 
Hall, Bronwyn H., and Beethika Khan. 2003. Adoption of New technology In NBER Working Paper Series Cambridge, MA: National Bureau of Economic Research

Hamilton, L.C. 2008. Statistics with Stata: Updated for version 10. Belmont, Calif: Brooks/Cole: Cengage Learning.

Hausman, Jerry, and Ephraim Leibtag. 2007. "Consumer Benefits from Increased Competition in Shopping Outlets: Measuring the Effect of Wal-Mart." Journal of Applied Econometrics 22 (7):1157-1177. doi: 10.1002/jae.994.

Heckman, James J. 1976. "The Common Structure of Statistical Models of Truncation, Sample Selection and Limited Dependent Variables and a Simple Estimator for Such Models." Annals of Economic and Social Measurement 5:475-492.

Hill, R. Carter, William E. Griffiths, and G. C. Lim. 2011. Principles of Econometrics. 4th ed. Hoboken, NJ: Wiley.

Hossain, Md Motaher. 2010. "Role of Technology in Consumption and Everyday Life in Rural Bangladesh." Technology in Society 32 (2):130-136. doi: 10.1016/j.techsoc.2010.03.004.

Jayasinghe, Maneka, Christine Smith, Andreas Chai, and Shyama Ratnasiri. 2016. "The Implications of Income Dependent Equivalence Scales for Measuring Poverty in Sri Lanka." International Journal of Social Economics 43 (12):1-17. doi: DOI 10.1108/IJSE-03-2015-0061.

Kakwani, Nanak, and Hyun H. Son. 2005. "Economies of Scale in Household Consumption: With Application to Australia." Australian Economic Papers 44 (2):134-148. doi: 10.1111/j.1467-8454.2005.00254.x.

Kanagawa, Makoto, and Toshihiko Nakata. 2008. "Assessment of Access to Electricity and the Socio-economic Impacts in Rural Areas of Developing Countries." Energy Policy 36 (6):2016-2029. doi: doi:10.1016/j.enpol.2008.01.041.

Lanjouw, Peter, and Martin Ravallion. 1995. "Poverty and Household Size." The Economic Journal 105 (433):1415-1434.

Logan, Trevon D. 2011. "Economies of Scale in the Household: Puzzles and Patterns from the American Past." Economic inquiry 49 (4):1008-1028.

Louw, Kate, Beatrice Conradie, Mark Howells, and Marcus Dekenah. 2008. "Determinants of Electricity Demand for Newly Electrified Low-income African Households." Energy Policy 36 (8):2812-2818. doi: 10.1016/j.enpol.2008.02.032.

Meenakshi, J. V., and Ranjan Ray. 2002. "Impact of Household Size and Family Composition on Poverty in Rural India." Journal of Policy Modeling 24 (6):539-559.

Mokyr, Joel. 2000. "Why "More Work for Mother?" Knowledge and Household Behavior, 1870-1945." The Journal of Economic History 60 (1):1-41. doi: 10.1017/S0022050700000012.

Nelson, Julie A. 1988. "Household Economies of Scale in Consumption: Theory and Evidence." Econometrica 56 (6):1301-1314.

Nelson, Julie A. 1993. "Household Equivalence Scales: Theory versus Policy?" Journal of Labor Economics 11 (3):471-493.

Ouedraogo, Boukary. 2006. "Household Energy Preferences for Cooking in Urban Ouagadougou, Burkina Faso." Energy Policy 34 (18):3787-3795. doi: 10.1016/j.enpol.2005.09.006.

Pena, Daniel, and Javier Ruiz-Castillo. 1998. "The Estimation of Food Expenditures from Household Budget Data in the Presence of Bulk Purchase." Journal of Business \& Economic Statistics 16 (3):292.

Popkin, Barry M. 1999. "Urbanization, Lifestyle Changes and the Nutrition Transition." World Development 27 (11):1905-1916. doi: 10.1016/S0305-750X(99)00094-7. 
Reardon, Thomas, C. Peter Timmer, Christopher B. Barrett, and Julio Berdegué. 2003. "The Rise of Supermarkets in Africa, Asia, and Latin America." American Journal of Agricultural Economics 85 (5):1140-1146. doi: 10.1111/j.0092-5853.2003.00520.x.

Siyambalapitiya, Tilak. 2002. "A Review of the Energy Policy in Sri Lanka and Its Implementation." Energy for Sustainable Development 6 (1):5-13. doi: 10.1016/S0973-0826(08)60293-8.

Tuttle, Brad. 2011. "Buying in Bulk: Trimming Food Bills Beyond the Warehouse Stores." accessed 3rd March. http://business.time.com/2011/01/13/buying-in-bulk-trimmingfood-bills-beyond-the-warehouse-stores/.

Vanek, Joann. 1978. "Household Technology and Social Status: Rising Living Standards and Status and Residence Differences in Housework." Technology and Culture 19 (3):361-375. doi: Doi 10.2307/3103370.

Vernon, Victoria. 2005. In Food Expenditure, Food Preparation Time and Household Economies of Scale. State University of New York: Fashion Institute of Technology.

Wickramasinghe, Anoja. 2011. "Energy Access and Transition to Cleaner Cooking Fuels and Technologies in Sri Lanka: Issues and Policy Limitations." Energy Policy 39 (12):7567-7574. doi: 10.1016/j.enpol.2011.07.032. 


\begin{tabular}{|c|c|c|c|c|}
\hline & National & Urban & Rural & Estate \\
\hline Number of households & 18,819 & 4,963 & 12,192 & 1,664 \\
\hline Male headed household & 14,406 & 3,624 & 9,506 & 1,276 \\
\hline $\begin{array}{l}\text { Percentage of households with access } \\
\text { to electricity }\end{array}$ & 86 & 95 & 84 & 72 \\
\hline Household size (n) & 4.3 & 4.4 & 4.2 & 4.5 \\
\hline Age of the head of the household (yrs) & 50.5 & 50.8 & 50.6 & 49.1 \\
\hline
\end{tabular}

sample

Source: Author's compilation based on Department of Census and Statistics (2011) 
Table 2: Average monthly expenditure share on food and non-food items, by sector

\begin{tabular}{|c|c|c|c|c|}
\hline & \multicolumn{4}{|c|}{ Expenditure share (of total household expenditure) } \\
\hline & National & Urban & Rural & Estate \\
\hline Total Food and beverages & 0.44 & 0.41 & 0.45 & 0.51 \\
\hline Alcohol & 0.03 & 0.02 & 0.02 & 0.05 \\
\hline Total Non-food items & 0.53 & 0.57 & 0.53 & 0.44 \\
\hline \multicolumn{5}{|l|}{ Non-food expenditure sub-categories } \\
\hline Health and Personal care & 0.04 & 0.05 & 0.04 & 0.04 \\
\hline Transport and Communication & 0.09 & 0.09 & 0.10 & 0.06 \\
\hline Recreation and education & 0.04 & 0.05 & 0.04 & 0.03 \\
\hline Clothing and Other & 0.16 & 0.15 & 0.17 & 0.18 \\
\hline Housing & 0.18 & 0.22 & 0.16 & 0.11 \\
\hline Electricity & 0.02 & 0.02 & 0.02 & 0.01 \\
\hline
\end{tabular}

Source: Author's calculations based on Department of Census and Statistics (2011) 
Table 3: IV Regression estimates - Per-capita expenditure on food

\begin{tabular}{|c|c|c|c|c|}
\hline \multirow[t]{2}{*}{ Independent variables } & \multicolumn{2}{|c|}{$\begin{array}{c}\text { Model I } \\
\text { First-stage Regressions }\end{array}$} & \multicolumn{2}{|c|}{$\begin{array}{c}\text { Model II } \\
\begin{array}{c}\text { Instrumental Variables } \\
\text { regression }\end{array} \\
\end{array}$} \\
\hline & Coefficient & S.E & Coefficient & S.E \\
\hline Constant $\left(\boldsymbol{\beta}_{\mathbf{0}}\right)$ & $9.630^{*}$ & 0.021 & $2.384^{*}$ & 0.512 \\
\hline Log of household size $\left(\boldsymbol{\beta}_{\mathbf{1}}\right)$ & $-0.511^{*}$ & 0.009 & $-0.124^{*}$ & 0.025 \\
\hline Log of electricity expenditure share $\left(\boldsymbol{\beta}_{2}\right)$ & $2.406^{*}$ & 0.236 & $-0.692^{*}$ & 0.171 \\
\hline Log of per-capita expenditure $\left(\boldsymbol{\beta}_{3}\right)$ & & & $0.661^{*}$ & 0.053 \\
\hline Number of employed $\left(\boldsymbol{\beta}_{\mathbf{4}}\right)$ & $0.045^{*}$ & 0.004 & & \\
\hline \multicolumn{5}{|l|}{ Vector of demographic variables $\left(\boldsymbol{\delta}_{\boldsymbol{i}}\right)$} \\
\hline Gender of the head of the household & $-0.090^{*}$ & 0.009 & -0.004 & 0.007 \\
\hline Rural dummy & $-0.253^{*}$ & 0.009 & -0.005 & 0.014 \\
\hline Estate dummy & -0.489 & 0.014 & -0.026 & 0.025 \\
\hline R squared & 0.1934 & & & 0.5885 \\
\hline \multirow[t]{2}{*}{ F statistic } & \multicolumn{2}{|c|}{$\mathrm{F}(6,18812)=731$} & \multicolumn{2}{|c|}{$\chi_{6}^{2}=10328$} \\
\hline & \multicolumn{2}{|c|}{$P$-value $=0.0000$} & \multicolumn{2}{|c|}{ P-value $=0.0000$} \\
\hline Number of observations & 18,819 & & & 18,819 \\
\hline
\end{tabular}

Notes: The dependent variable in model I is log of PCE. The dependent variable in model II is the log of per-capita food expenditure. $*$ indicates significance at the 5 per cent level

Source: Author's calculations based on Department of Census and Statistics (2011) 
Table 4: Test of endogeneity

Robust score $\chi_{1}^{2}=\quad=10.5169(\mathrm{p}=0.0012)$

Robust regression $\mathrm{F}(1,18811)$

$=10.5595(\mathrm{p}=0.0012)$

Table 5: Test for weak instruments

\begin{tabular}{lllllc}
\hline Variable & R squared & $\begin{array}{l}\text { Adjusted R } \\
\text { squared }\end{array}$ & $\begin{array}{l}\text { Partial R } \\
\text { squared }\end{array}$ & Robust & Prob $>$ F \\
\hline Log of PCE & 0.1934 & 0.1932 & 0.0047 & 92.2868 & 0.0000 \\
\hline
\end{tabular}


Table 6: Heckman two-step model estimates: economies of scale in technology consumption

\begin{tabular}{|c|c|c|}
\hline \multicolumn{3}{|c|}{ Output equation - Dependent Variable: Electricity Expenditure } \\
\hline & Coefficient & S.E \\
\hline Constant $\left(\boldsymbol{\beta}_{\mathbf{0}}\right)$ & $-3020.719^{*}$ & 176.351 \\
\hline Household size $\left(\boldsymbol{\beta}_{1}\right)$ & $183.641^{*}$ & 15.639 \\
\hline Square of household size $\left(\boldsymbol{\beta}_{2}\right)$ & $-5.714^{*}$ & 1.304 \\
\hline Log of PCI $\left(\boldsymbol{\beta}_{3}\right)$ & $372.937^{*}$ & 16.156 \\
\hline \multicolumn{3}{|l|}{ Vector of demographic variables $(\boldsymbol{\delta})$} \\
\hline Rural & $-489.302^{*}$ & 22.176 \\
\hline Estate & $-781.542^{*}$ & 43.074 \\
\hline \multicolumn{3}{|c|}{$\begin{array}{l}\text { Selection equation - Dependent Variable: Dummy variable on the } \\
\text { Probability of spending on electricity }\end{array}$} \\
\hline & Coefficient & S.E \\
\hline Constant $\left(\boldsymbol{\beta}_{\mathbf{0}}\right)$ & $-3.122^{*}$ & 0.172 \\
\hline Household size $\left(\boldsymbol{\beta}_{\mathbf{1}}\right)$ & $0.304^{*}$ & 0.021 \\
\hline Square of household size $\left(\boldsymbol{\beta}_{2}\right)$ & $-0.019^{*}$ & 0.002 \\
\hline $\log$ of PCI $\left(\boldsymbol{\beta}_{3}\right)$ & $0.389^{*}$ & 0.015 \\
\hline \multicolumn{3}{|l|}{ Vector of demographic variables $(\boldsymbol{\delta})$} \\
\hline Rural & $-0.587^{*}$ & 0.034 \\
\hline Estate & $-0.964^{*}$ & 0.045 \\
\hline Gender of the head of the household & $0.063^{*}$ & 0.029 \\
\hline Age of the head of the household & $0.011^{*}$ & 0.001 \\
\hline \multicolumn{3}{|l|}{ Mills } \\
\hline$\lambda$ & $912.277^{*}$ & 106.027 \\
\hline rho & & 1.000 \\
\hline sigma & & 912.277 \\
\hline Number of observations & & 18819 \\
\hline Censored observations & & 2661 \\
\hline Uncensored observations & & 16158 \\
\hline$\chi_{5}^{2}$ & & 811.21 \\
\hline$P$ - value & & 0.0000 \\
\hline
\end{tabular}

Notes: * indicates significance at the 5 per cent level

Source: Author's calculations based on Department of Census and Statistics (2011) 
Table 7: Percentage of household moved out of poverty in the sample

\begin{tabular}{|c|c|c|c|}
\hline & $\begin{array}{c}\text { Poor households } \\
\text { under PCE }\end{array}$ & $\begin{array}{l}\text { Poor households after } \\
\text { adjusting for scale } \\
\text { economies food } \\
\text { consumption due to } \\
\text { domestic technology } \\
\text { adoption } \\
\end{array}$ & $\begin{array}{l}\text { Percentage } \\
\text { decline in poor } \\
\text { households }\end{array}$ \\
\hline National & 1800 & 614 & $65.9 \%$ \\
\hline Urban & 222 & 62 & $72.1 \%$ \\
\hline Rural & 1247 & 438 & $64.9 \%$ \\
\hline Estate & 331 & 114 & $65.6 \%$ \\
\hline
\end{tabular}

based on Department of Census and Statistics (2011) 
Figure 1: Percentage of households with access to electricity

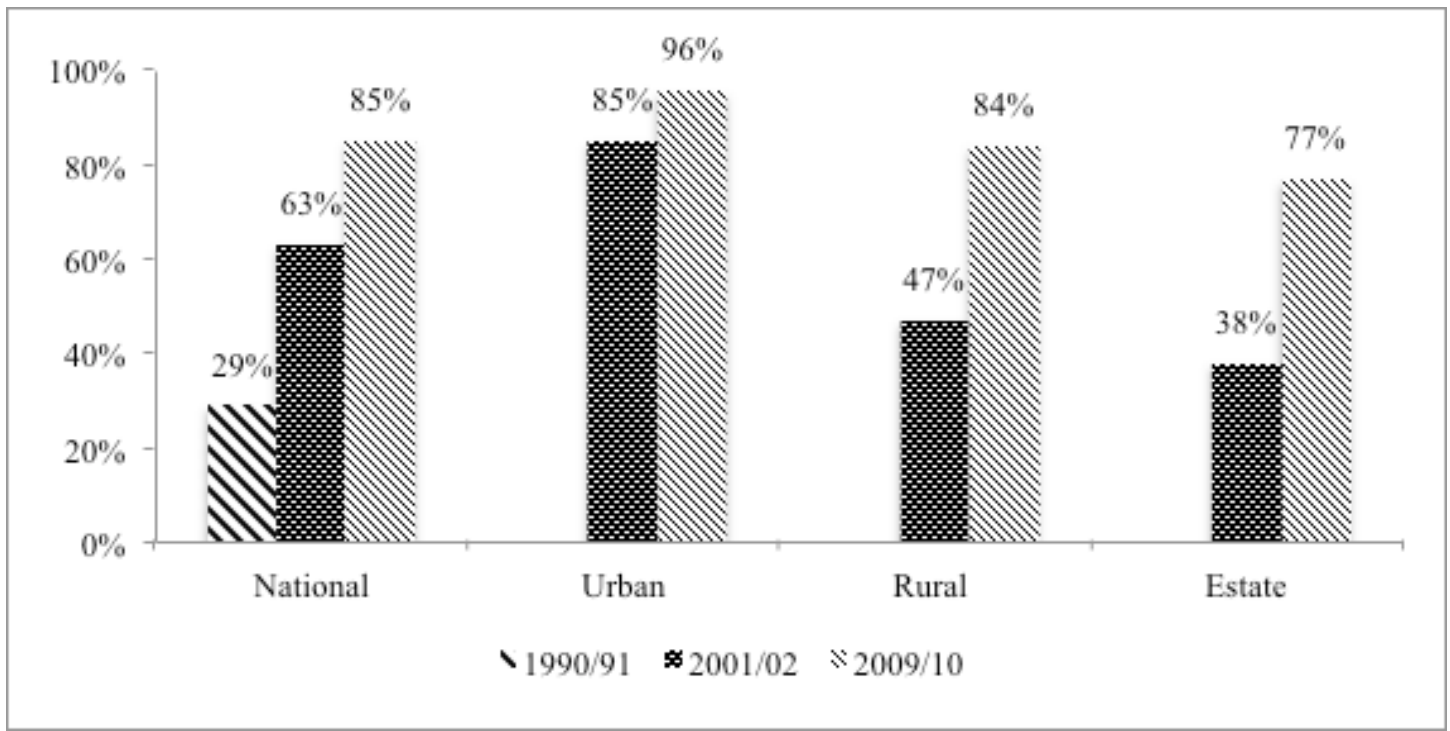

Source: Ceylon Electricity Board, 2008, 2011

Note: The data on sectoral level percentage access to electricity is not available for 1990/91 